\title{
Developing Community Disaster Resilience in Lembang Fault Area, Indonesia: Lessons Learned from Japanese Experience
}

\section{Rizqi Abdulharis $^{1^{*}}$, Alfita P. Handayani ${ }^{1}$, Chikako Isouchi ${ }^{2}$ and Irwan Meilano ${ }^{1}$}

${ }^{1}$ Surveying and Cadastre Research Division, Department of Geodetic and Geomatics Engineering, Gedung Labtek IX-C, $2^{\text {nd }}$ floor, Jl. Ganesa no. 10, Kota Bandung 40132, Province of Western Java, Indonesia

${ }^{2}$ Institute of Education, Research and Regional Cooperation for Crisis Management Shikoku, Kagawa University, 1-1 Saiwai-cho, Takamatsu, 760-8521, Japan

* Corresponding author: rabdulharis@gd.itb.ac.id

Abstract: Having experienced large-scale disasters between 2004 and 2006, the fatalities due to large-scale disasters in 2018 were still high. In contrast, disaster risk management (DRM) and CDR in Japan have been continuously improved. Thus, there is a need to develop CDR for supporting DRM in Indonesia by learning from the Japanese experience, particularly in a disaster-prone area without large-scale disaster experience. This research was a pilot project on the development of CDR in Indonesia. The case study was a geological hazard-prone Lembang Fault area. People's perception was collected using structured interviews, while demographic and local economic data was acquired from official statistical publications. Satellite imageries were utilized to acquire natural and built environment and land use/land cover and their changes between 2019 and 2021. Although the degrees of social capital, risk knowledge including indigenous knowledge and past disaster experience were high, government interventions on DRM and land administration are required to develop CDR in Lembang Fault area. Organized community development is expected rather than to solely involve NGOs. Moreover, strategies to develop economic resilience are needed to allow the community to bounce back from future disaster. Finally, a detail baseline data should be collected to develop DRM strategy and CDR.

Keywords: Community disaster resilience, Lembang Fault, Indonesia, Japan

\section{Introduction}

Community disaster resilience (CDR) is pivotal to disaster risk management (DSR). CDR is defined as an ability of a system, community or society exposed to hazards to resist, absorb, accommodate to and recover from the effects of a hazard in a timely and efficient manner, including through the preservation and restoration of its essential basic structures and functions, while DSR is described as a systematic process of using administrative directives, organizations and operational skills and capacities to implement strategies, policies and improved coping capacities in order to lessen the adverse impact of hazards and the possibility of disaster [1]. Although DSR covers activities on prevention, mitigation, preparedness, response and recovery from disaster, it is dominated by response and recovery activities [2]. On the other hand, CDR focuses on mitigation and preparedness activities, as well as recovery processes [3]. Moreover, the emphasis of CDR is to reduce impacts of disaster $[2,4]$. Thus, CDR becomes an important part of DRM.

The degrees of DRM and CDR in Indonesia are arguably low. Having experienced large-scale disasters caused by earthquakes and tsunamis between 2004 and 2006, the number of fatalities caused by another large-scale disasters in 2018 were still high. Such facts have created uneasiness to the people of Indonesia as the number of disasters had been increasing between 2018 and 2020. See Figure 1 for details. 
On the other hand, the DRM and CDR development in Japan have been continuously improved. Due to the lessons learned from Typhoon Ise Bay in 1959, the Japanese Government enacted the Disaster Countermeasure Basic Act. The mentioned act was revised in 2011 as the Great East Japan Earthquake was still caused more than 20,000 casualties. In recent years, non-structural measures on DRM, such as disaster education and planning has become more important. This is primarily because public sector was also damaged due to 2011 Great East Japan Earthquake. DRM has been incorporated into the elementary school curriculum across the board. Such measures include participation of private and community sector. In addition, there are some examples of joint disaster prevention mapping and disaster drills with residents. Above all, structural measures that include the construction of protective facilities have still been performed.

CDR has also been studied in Indonesia. There are five CDR domains, namely social, economic, institutional, infrastructural and environmental domains, based on experiences of various stakeholders whom recently experiencing large-scale disaster events in Indonesia [5], while such domains were implemented to quantitatively assess CDR on flood disaster in a district, or kecamatan in Bahasa Indonesia, in Municipality of Bojonegoro of Eastern Java Province [6]. Another research was focusing on assessment of social domain of CDR in post-disaster area [7].

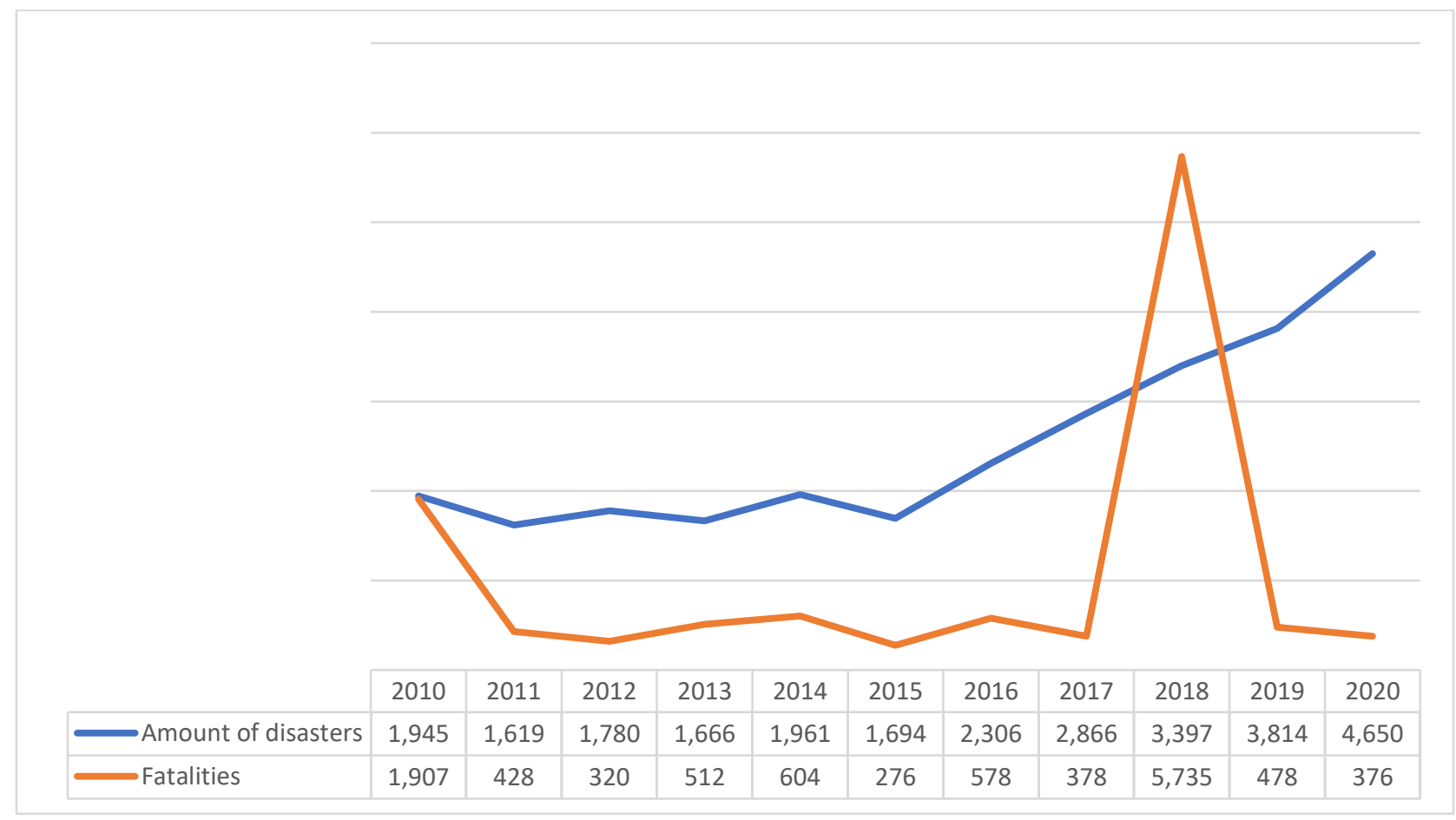

Figure 1 The number of disaster and fatalities in Indonesia between 2010 and 2020

Unfortunately, there is a lack of information on CDR development in disaster-prone area. Moreover, there is no explanation yet on difficulties to relocate people to a safer area such as in Municipality of Banda Aceh of Aceh Province after 2004 Indian Ocean Tsunami [8], as well as in Municipality of Pandeglang of Banten Province after 2018 Sunda Strait Tsunami and in Municipality of Sukabumi of Western Java Province after 2018 landslide [7].

Among the objectives of the research that is highlighted in this paper was to develop community resilience to disaster in Indonesia. The research considered Japanese experience on developing CDR. This research also put in mind special social, economic, institutional, infrastructural and environmental characteristics of Indonesia. Most importantly, the research focused on the development of CDR in a disaster-prone area to explore the possibility to develop a resilient 
community that has not experienced a large-scale disaster. It is expected that the community will be adequately resilient in case of the occurrence of various scale of disaster.

Furthermore, the mentioned research was not intended to assess the degree of community resilience in Indonesia. Rather, the research was focusing on closing the gaps on CDR development on each sub-category. Also, this paper highlights completeness of data concerning existing CDR condition.

To initiate the development of CDR in a disaster-prone area without any experience on a large-scale disaster occurrence, Lembang Fault area was chosen as the pilot. Extending approximately $29 \mathrm{~km}$ in west-east direction to the north of Muncipality of City of Bandung, Lembang Fault area is a geological hazard-prone area. With the annual fault movement of $6 \mathrm{~mm}$ [9], Lembang Fault activity may produce an earthquake with a magnitude between 6.5 and $7.0 \mathrm{Mw}$ with a repetition time between 170 and 670 years [10].

\section{Materials and Methods}

The research employed case study approach. The focus of the highlighted study was the central part of Lembang Fault, which is in Municipality of Western Bandung and Municipality of City of Bandung. The analysis CDR unit was the central part of Lembang Fault area, which comprises of four districts in Lembang Fault area, namely District of Parongpong, Cisarua, Lembang of Municipality of Western Bandung and District of Sukasari of Municipality of City of Bandung. To provide an overview of demographic and local economic characteristics of the case study area, the publications of Statistics Indonesia, or Badan Pusat Statistik/BPS in Bahasa Indonesia, on social and economic statistics of the four districts were utilized. For acquiring information concerning natural and built environment and land use/land cover, as well as their changes between 2019 and 2021, Level 2A Sentinel-2 satellite imageries that have been geometrically corrected by means of Bottom of Atmosphere (BOA) radiometric correction of reflectance were employed. See Figure 2, Figure 3 and Figure 4 for details. Information concerning policy, regulations and procedures on DRM was acquired from regulations at national, provincial and local level. Furthermore, two types of interviews were performed. First, to acquire information on social capital and culture, as well as risk knowledge particularly indigenous knowledge on risks in Lembang Fault area, key informants were interviewed. Second, to obtain a deeper understanding concerning people's perception in the scope of other sub-categories of CDR, interviews were conducted to 108 respondents who live in 14 villages within four districts of Lembang Fault area. See Figure 5 for the location of survey of this research. The highlighted research also collected information on Japanese experience on development of CDR, which information is a result of a long-term research on CDR. 


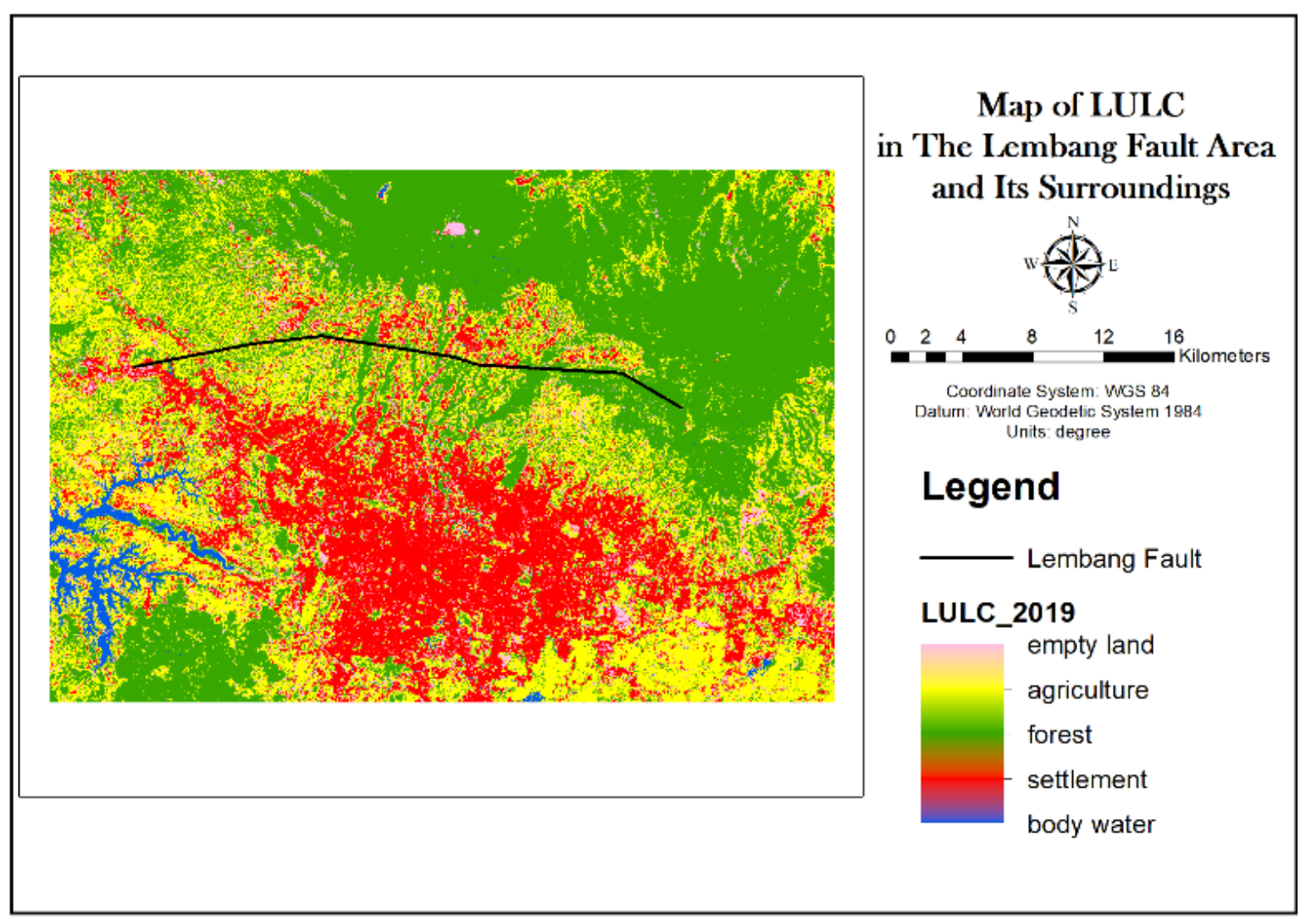

Figure 2 Land use/land cover of Lembang Fault area of 2019

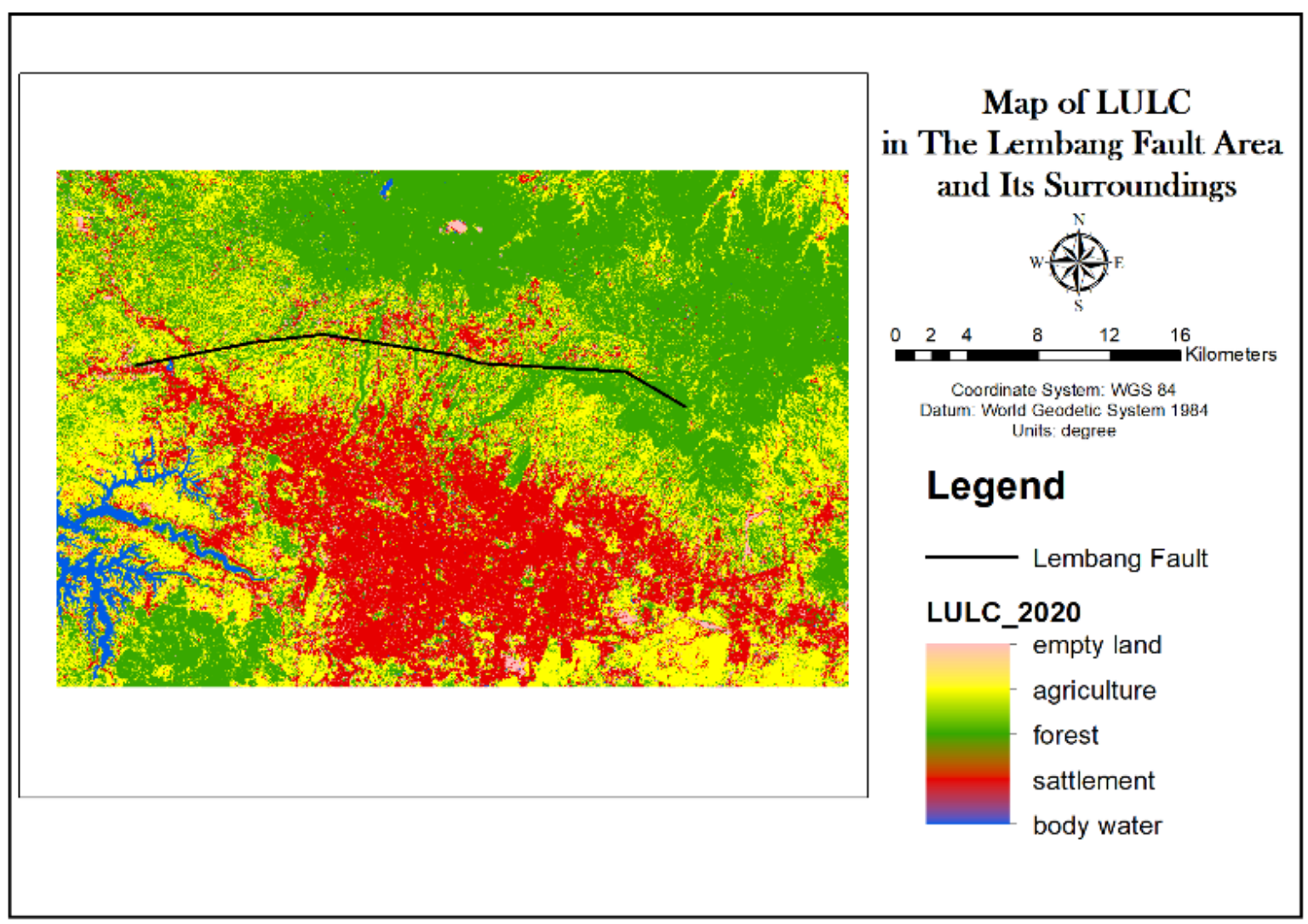

Figure 3 Land use/land cover of Lembang Fault area of 2020 


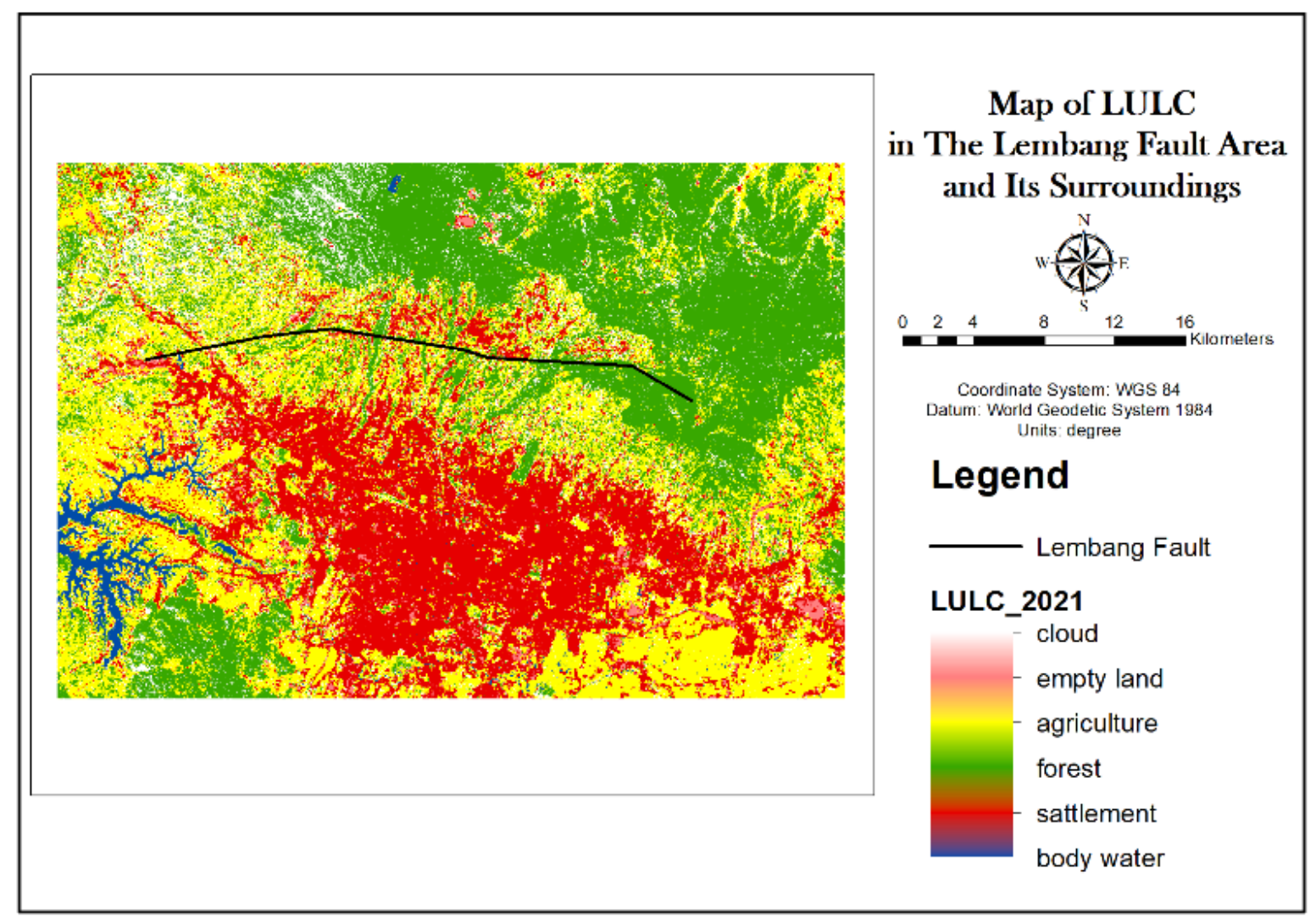

Figure 4 Land use/land cover of Lembang Fault area of 2021

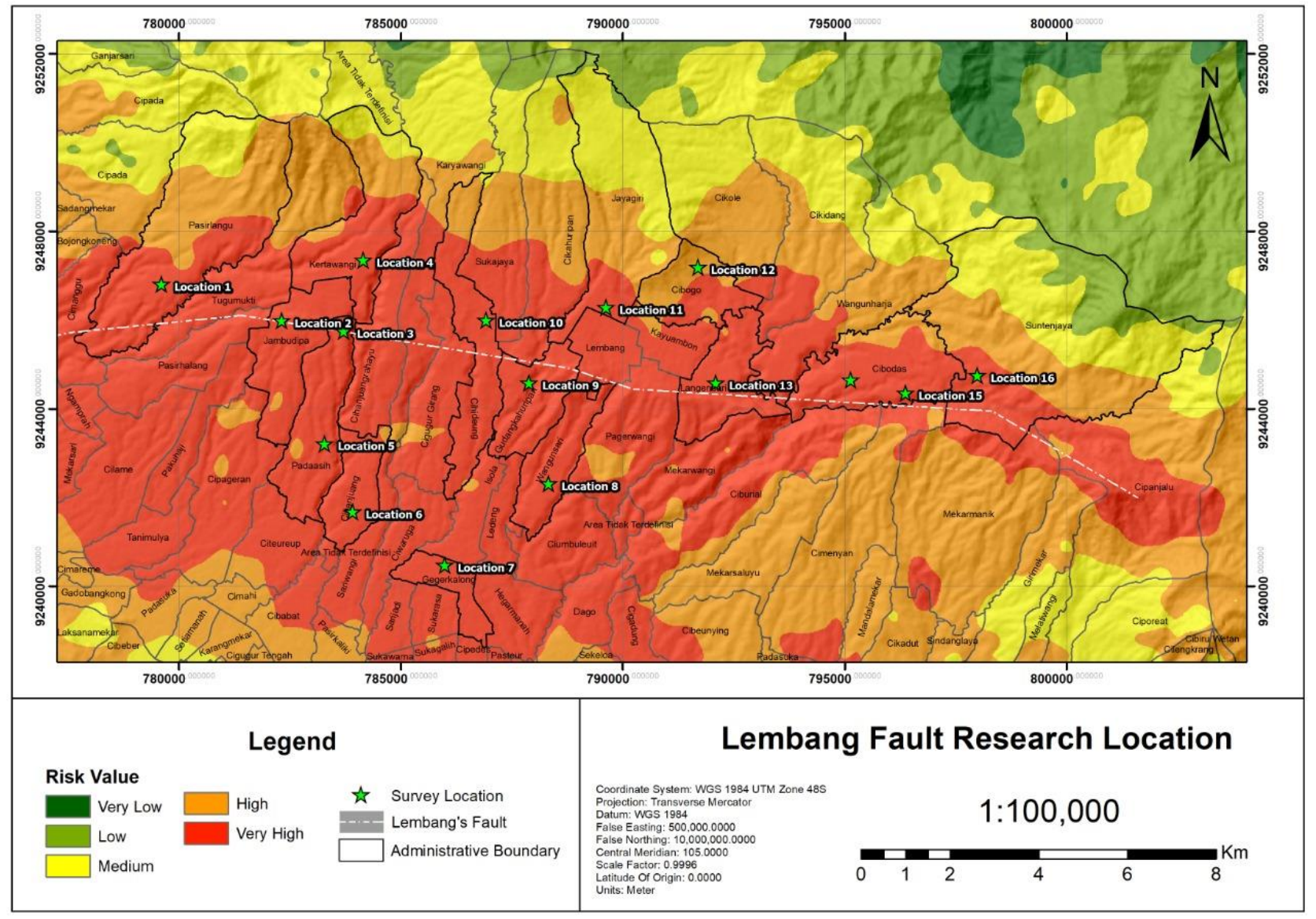

Figure 5 Location of survey in Lembang Fault area 
The collected data was analyzed by means of classificational analysis method. Having developed the research's conceptual framework based on CDR concepts and the Japanese experience, the acquired data was classified. The output of the analysis was the existing gaps on CDR development in Lembang Fault area.

\section{Theory}

In this section, the domains and their sub-categories in the scope of assessment of CDR were given. The domains and their sub-categories were utilized as the framework on assessment of CDR in the research that is highlighted in this paper. See Table 1 for the domains and sub-categories for CDR assessment.

Table 1 Domains and sub-categories of community disaster resilience assessment

\begin{tabular}{|c|c|}
\hline Domain & Sub-category \\
\hline Social & $\begin{array}{l}\text { - } \text { Demography } \\
\text { - Social capital and cultural characteristics } \\
\text { - Risk knowledge } \\
\text { - Participation } \\
\text { - People capacity on DRM }\end{array}$ \\
\hline Economic & $\begin{array}{l}\text { - Local economy } \\
\text { - Individual livelihood }\end{array}$ \\
\hline Institutional & $\begin{array}{l}\text { - } \text { Policy and regulations } \\
\text { - Procedures on DRM } \\
\text { - Organized governmental services } \\
\text { - Cooperation among government institution, NGOs and the community }\end{array}$ \\
\hline Infrastructural & $\begin{array}{l}\text { - } \quad \text { Transportation infrastructure } \\
\text { - } \quad \text { Disaster management infrastructure } \\
\text { - Land use } \\
\text { - Structural design }\end{array}$ \\
\hline Environmental & $\begin{array}{l}\text { - Natural environment condition } \\
\text { - Built environment condition } \\
\text { - Types of disaster } \\
\text { - Levels of hazard }\end{array}$ \\
\hline Land administration & $\begin{array}{l}\text { - Social function of land } \\
\text { - } \quad \text { Economic function of land } \\
\text { - Physical function of land } \\
\text { - } \\
\end{array}$ \\
\hline
\end{tabular}

\subsection{Community Disaster Resilience}

Comprehensive assessment of CDR has been mainly done by considering social, economic, institutional, infrastructural and environmental domain [5,11,12]. An assessment framework was proposed based on several literatures by considering local risks, vulnerabilities and the scale of the anticipated disaster [11], while another framework was developed based on several resilience indexes, namely Baseline Resilience Index for Communities, Climate Disaster Resilience Index and Community Disaster Resilience Index [12]. On the other hand, suggestions from government agencies, NGOs, community leaders and business community were collected for developing such a framework [5]. 
Social domain comprises sub-categories on demography, social capital and cultural characteristics $[5,11,12]$. While risk knowledge is considered as another important factor that should be considered $[5,12]$, it is proposed that people capacity on DRM should be included as an assessment parameter in this domain [12]. In addition, it is suggested that participation to be included on the assessment of this domain [5].

From the perspective of institutional domain, institutional capacity on DRM namely the existence of policy, regulation and procedures on warning and evacuation, responding and recovering from disaster [5,11,12], as well as mitigation plan [5], are proposed to assess CDR. Additionally, participation and cooperation among government institution, NGOs and the community [5], as well as organized governmental services [12] are also pivotal to assess CDR in this domain.

On economic domain, the means of individual livelihood and local economy is substantially important to be assessed, while transportation infrastructure is noticeably important among the vital sub-categories on infrastructural domain [5,11,12]. Disaster management infrastructure, land use and structural design is also considered as parameters on the assessment of CDR from the infrastructural perspective [12].

For the environmental domain, there are several important assessment parameters. These parameters are natural environment condition [5,11,12], built environment condition [11] and types of disaster and their levels of hazard [5].

\subsection{Land Administration on Community Disaster Resilience}

Concerning issues on relocating people during the recovery phase to a safer place, land administration is proposed as a domain on the assessment of CDR. People who were affected by 2018 landslide in Municipality of Sukabumi and 2018 tsunami in Municipality of Pandeglang [7], as well as casualties of 2004 tsunami in Municipality of Banda Aceh [8], were returning to their land even though the areas were already defined as restricted zones due to their proneness to the related disaster. The main reason for the fatalities caused by 2018 landslide in Municipality of Sukabumi and 2018 tsunami in Municipality of Pandeglang to return to their land or nearby areas was the strong connection between the people and their land [7].

Land administration is defined as a process run by government using public or private sector agencies related to land tenure, land value, land use and land development [13]. Land administration regulates relationship between people and land by defining rights, restrictions, and responsibilities of the people to their land [14]. The successfulness of the mentioned process is mostly depending on the existence of a sound land administration system, which is an infrastructure for implementation of land policies and land management strategies, while land management is an activity associated with the management of land to achieve sustainable development goals [13].

While land administration regulates the existing relationship, it is argued that such a relationship may be intervened. In the scope of disaster risk management, relocating people, particularly those who were affected by disaster, to a safer zone is considered as among the interventions to people-land relationship. Furthermore, land administration may regulate people-land relationship at every phase of disaster risk management [15]. Thus, land administration is a powerful tool to ensure a successful disaster risk management.

Furthermore, land administration plays an important role on recovery from disaster, as well as developing CDR. The revision of spatial planning of Municipality of Banda Aceh was one of the important processes at the recovery phase of 2004 Great Tsunami of Aceh [8]. The spatial plan was 
developed based on the proneness of the municipality to tsunami, which pushed the residential areas to the safer ground. At the recovery phase after 2018 Lombok Island Great Earthquake, land readjustment was initiated to create safer neighborhoods in Lombok Island [16]. The dense settlements, unreliable houses and inadequate access to evacuation areas were among the main causes of casualties in the mentioned earthquake, which became the main considerations on the performance of land readjustment [17].

A good land tenure system has been proven to facilitate the disaster recovery phase, as well as to lead to a resilient community to disaster. Due to 2004 Great Tsunami of Aceh, official land records were mostly damaged [8]. On the other hand, during the recovery phase of 2018 Great Earthquake of Lombok Island, land readjustment process included the first-time land registration for most of affected parcels [16].

In the scope of development of CDR, several sub-categories were proposed. The sub-categories are social, economic and physical functions of land for the people and community. These sub-categories were proposed based on social, economic and physical domain of people-land relationship [13].

\section{Results}

\subsection{Lembang Fault Area}

In this section, the description of CDR in Lembang Fault area from the perspective of the previously mentioned domains and sub-categories is given. In social domain, demography sub-category comprises of assessment on proportion of population's age, disability, gender, educational level and wealth [11]. While statistics on gender and educational level of the four districts is available, population's age data is only existed for Sukasari District. On the other hand, statistics on disability and wealth at district level is not available. In Sukasari District, the population was dominated by productive age group between 15 and 64-year-old. The proportion of women and men in the four districts is equal. On the other hand, in Sukasari and Lembang District, more than $30 \%$ of population were senior high school graduates, while the proportion of elementary school graduates who were not pursuing further education in Parongpong and Cisarua District is the highest in the latter mentioned districts.

The degree of social capital of people in Lembang Fault area was noticeably high. According to Teo et al. (2015), social capital is defined as quality of relationships among individuals and at community level that contribute to community resilience, particularly concerning bonding among people and community with similar characteristics, bridging between people and community with different characteristics and linking that reveals the vertical connection of the people and community to people and community at the higher level. According to Tjokropandojo et al. (2019), the social capital of people who live in Lembang Fault area is significantly high, particularly concerning bonding and bridging. On the other hand, the degree of linking in the scope of social capital concerning DRM is very low, as there were on $8.33 \%$ of the respondents who have interacted with the government institutions and NGOs in the scope of DRM.

Concerning the knowledge on proneness of the area, $75 \%$ of the respondents understood the risk of living in Lembang Fault area. 34.26\% of the respondents acquired such an information from mass media such as television, while $28.70 \%$ of the respondents learnt the information from social media. The knowledge has also been passed on to the people in the area as $25.93 \%$ of the respondents got the information from their neighbors, village government and/or personal experience. Furthermore, there exists indigenous knowledge concerning the proneness of the area in several historical manuscript. Also, the indigenous risk knowledge has been passed on through traditional performance, while names of several places reveal the knowledge on proneness of the area. 
The degree of participation of the respondents on disaster risk management is considerably low. $24.07 \%$ of the respondents agreed that disaster mitigation should be done by means of environmental protection, disaster response simulation, disaster risk management education and promoting disasterresistant structure. However, $37.97 \%$ of the respondents thought that it is not necessary to perform disaster mitigation, while $37.96 \%$ of the respondents did not know whether such an effort is necessary. Such an attitude led to a low degree of participation as $66.66 \%$ of the respondents thought that there is nothing they could do to mitigate and/or to response the disaster.

The people's capacity on DRM is also low. $20.37 \%$ of the respondents said that there is nothing they should do during disaster occurrence, while $45.37 \%$ of the respondents did not know what to do. While the rests of the respondents mentioned that some actions should be taken during disaster occurrence, the knowledge of the respondents on the matter was very limited and inadequate to response the possible disaster in the area.

During the fieldwork of the highlighted research, the information on past disaster experience was also collected. $97.22 \%$ of the respondents have experienced earthquakes in the area, while there are $12.04 \%$ of the respondents who have experienced disaster occurrence in other areas. $50 \%$ of the respondents who have experienced earthquakes in the area feel anxious due to the events, $12.96 \%$ were more alert on the proneness of the earthquakes, while $31.48 \%$ of the respondents were getting used to the disaster. By considering statistics of other sub-categories in the social domain, it was concluded that past disaster experience increased the degree of risk knowledge but did not enhance people's participation and capacity on DRM.

In the economic domain, there are two sub-categories that are considered to develop CDR, namely local economy and individual livelihood. Local economy is defined as the degree of diversity of industries, which reveals the ability to revitalize the local economy, while individual livelihood is an ability of people to seek suitable employment that comprises of two sub-categories namely availability of jobs to suit dignity and availability of alternate employment (Teo et al., 2015). In Cisarua, Lembang and Parongpong District, the local economy was spearheaded by agricultural sector. Particularly in Lembang and Parongpong District, trading, particularly in the scope of tourism, also dominated citizens' employment. On the other hand, in Sukasari District, 57.56\% of the people were employed in services sector. In the latter, $28.70 \%$ of the respondents were labors, while $18.52 \%, 16.67 \%$ and $11.11 \%$ were traders, entrepreneurs and farmers respectively. This reveals that there has been less opportunity in agricultural sector compared to it of the industrial, trading and entrepreneurship sector.

DRM in Indonesia is regulated by Act number 24 of 2007 concerning Disaster Management. The mentioned act has been applied by the local governments in Lembang Fault area, particularly in the Municipality of Western Bandung. The Government of Municipality of Western Bandung has promulgated 2012 Municipal Decree on Spatial Plan, which plans the designation of disaster-prone areas, as well as evacuation zone and routes, for DRM in Lembang Fault area. Moreover, 2013 Municipal Decree on DRM has also been enacted to regulate DRM in general in the municipality and particularly in Lembang Fault Area. On the other hand, DRM procedures were not publicly available, while organized governmental services were not existed in the four districts. On the other hand, several NGOs have been promoting DRM activities, which encourage both the government institutions and the communities to collaborate. Nonetheless, because there were only $8.33 \%$ of the respondents acquired risk knowledge from such activities, it could be concluded that the coverage of the activities was considerably low.

Inter-district road network in the case study area is basically adequate to facilitate people's mobilization. However, $46.30 \%$ of the respondents mentioned that there is no DRM infrastructure, while $13.89 \%$ of the respondents did not know about such an infrastructure. Moreover, $40.74 \%$ of 
respondents stated that the access to the available DRM infrastructure was adequate, while $33.33 \%$ of the respondents mentioned that the access to DRM infrastructure was inadequate. Unfortunately, $25.93 \%$ of the respondents did not know whether there is access to the existing DRM infrastructure. In 2021, the land use/land cover of Lembang Fault area is dominated by agriculture areas and forest, which covers $35.85 \%$ and $35.00 \%$ of the case study area respectively. See Table 2 for the extent and proportion of land use/land cover between 2019 and 2021. On the house structure of the respondents, $87.04 \%$ of the respondents' houses were made of brick and/or concrete. However, the survey did not collect specific information concerning the durability of houses to disaster, although $24.07 \%$ of the respondents agreed that there should be structural reinforcement of their houses.

While the survey did not collect further information on the condition of natural and built environment, the extent of residential and agricultural areas between 2019 and 2021 were rising 34,476 square km or $13.41 \%$ and 46,528 square $\mathrm{km}$ or $12.40 \%$. On the other hand, the extent of the forest between 2019 and 2021 was decreasing from 546,007 square $\mathrm{km}$ to 411,644 square $\mathrm{km}$ or $24.61 \%$ of the total extent of the forest. See Table 2 for details. Furthermore, according to survey, 50\% of the respondents stated that their neighborhood is prone to earthquake, specifically due to Lembang Fault, while $19.44 \%$ of the respondents mentioned that their neighborhood is also prone to landslide and flood. As mentioned at the Introduction, the level of hazard, particularly concerning earthquake, in Lembang Fault area is considerably high.

On land administration domain, it is argued that the social connection between the people and their land was high. This is because most respondents have been living in the Lembang Fault area for more than 10 years. The economic connection between the people and their land was also high as $71.29 \%$ of the respondents' place of works were less than $5 \mathrm{~km}$. As the land use/land cover of the Lembang Fault area between 2019 and 2021 is dominated by agriculture land and forest, the dependency of the people living in Lembang Fault area to their environment was also high. Furthermore, there are existed policy and regulations DRM-related land administration, although, based on the survey, such policy and regulations have provided no impact to the people. Also, the respondents agreed that there were less activities on DRM-related land administration.

Table 2 Land use/land cover change between 2019 and 2021

\begin{tabular}{|c|c|c|c|c|c|c|c|c|c|}
\hline \multirow{3}{*}{ LULC } & \multirow{2}{*}{\multicolumn{3}{|c|}{ Extent $\left(\mathrm{km}^{2}\right)$}} & \multicolumn{6}{|c|}{ Land Use/Land Cover Change } \\
\hline & & & & \multicolumn{2}{|c|}{$2019-2020$} & \multicolumn{2}{|c|}{ 2020-2021 } & \multicolumn{2}{|c|}{ 2019-2021 } \\
\hline & 2019 & 2020 & 2021 & Extent $\left(\mathrm{km}^{2}\right)$ & $\%$ & Extent $\left(\mathrm{km}^{2}\right)$ & $\%$ & Extent $\left(\mathrm{km}^{2}\right)$ & $\%$ \\
\hline Body of Water & 25.111 & 27.468 & 25.844 & 2.357 & $9,39 \%$ & -1.624 & $-5,91 \%$ & 733 & $2,92 \%$ \\
\hline Settlement & 279.443 & 298.080 & 316.919 & 18.637 & $6,67 \%$ & 18.839 & $6,32 \%$ & 37.476 & $13,41 \%$ \\
\hline Forest & 546.007 & 528.249 & 411.644 & - 17.758 & $-3,25 \%$ & -116.605 & $-22,07 \%$ & -134.363 & $-24,61 \%$ \\
\hline Agriculture & 375.118 & 385.788 & 421.646 & 10.670 & $2,84 \%$ & 35.858 & $9,29 \%$ & 46.528 & $12,40 \%$ \\
\hline
\end{tabular}

\subsection{Japanese Experience}

This section introduces case studies of communities that have been engaged in activities aimed at improving community resilience, which proved successful in the face of disasters. Specifically, the case studies describe success stories on mitigation of damage by conducting community-based disaster risk management activities during normal times, as well as legalizing disaster warning zones for landslides that affected the former activities.

\section{Land Management for the Prevention of Sediment Disaster in Japan}

In Japan, the Act on Sediment Disaster Countermeasures for Sediment Disaster Prone Areas has been enacted as a legal regulation on Sediment disasters. The Sediment Disaster Prevention Act identifies 
areas in which sediment disaster is likely to occur and prescribes soft measures such as the establishment of warning and evacuation systems and structural regulations for buildings. This law was enacted based on the lessons learned from the torrential rains that occurred in Hiroshima Prefecture in 1999, which resulted in 325 sediment disaster and 24 fatalities [18].

Having been developed for regulating disaster risk management for steep slope collapses, landslides and debris flows, the mentioned act provides the following:

- Public awareness of areas at risk of sediment disaster

- Establishment of a warning and evacuation system

- Suppression of new housing development

- Support for relocation of houses and so forth.

This research was initiated to promote soft measures for implementation of the act. On the development of public awareness of areas at risk of sediment disaster, two types of areas were distinguished according to the level of hazard. The first zone is called the Sediment Disaster Special Hazard Areas, also known as red zone, and the second zone is called the Sediment Disaster Hazard Areas or yellow zone. After the enactment of the law, 663,258 sediment-disaster hazard warning areas were established nationwide as of the end of March 2021[19]. See Figure 6 for designation of warning areas for different types of disaster.

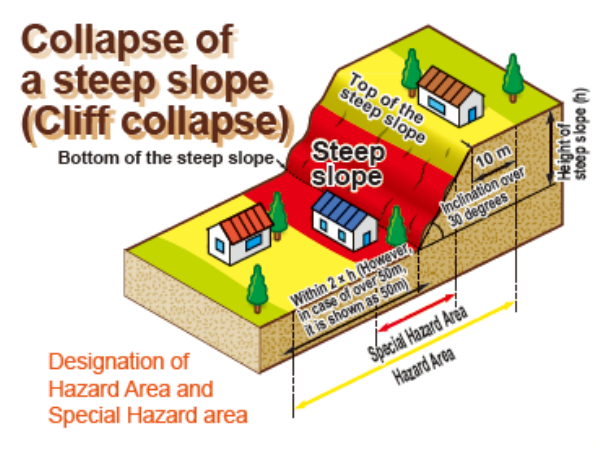

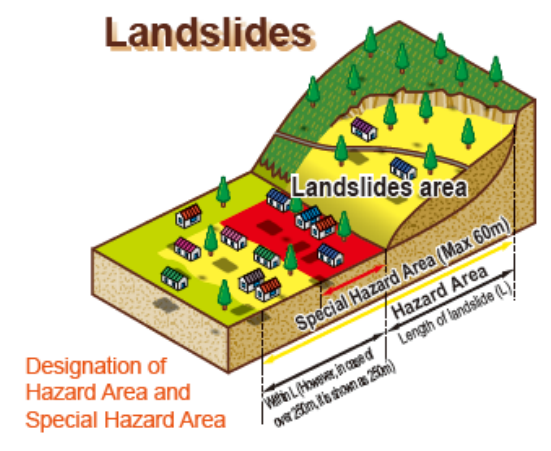

Figure 6 Designation of warning areas for different types of disaster [18]

\section{Initiatives in the Takahama District, Ehime Prefecture}

In this section, a case study was initiated in Takahama District of Ehime Prefecture, in which the sediment-disaster hazard warning area was established in 2015, to describe the effect of legal zoning. The case study was conducted by semi-structured interviews.

As Takahama District is facing the sea, the Tsunami inundation area of $1.2 \mathrm{~m}$ to $2.5 \mathrm{~m}$-depth is expected in $70 \%$ of the district. The topography of the area is densely populated with houses on the flat land between the sea, the main road and the hillside, some of which are old wooden houses. At the time of the disaster, the population was about 8,000, with an ageing rate of about $35 \%$. The ageing population was another issue that was faced by the district.

In the past, the district had suffered tremendous damage from high tides. In the forecast of the damage caused by the Nankai Trough earthquake, which is feared to occur in the future, it is assumed that seismic motion may not only lead to earthquakes but also tsunami, liquefaction and sediment disasters during heavy rainfall warnings occur. In addition, in dense wooden residential areas, there is also a rising concern on fires during earthquakes. 
Due to the geographical characteristics of the area, the voluntary disaster prevention organizations in the district took the lead in planning of the operation of evacuation centers and developing the basic rules for evacuation. Such an evacuation was expected to include the participation of the whole community, including primary and secondary schools, police, firefighters and companies [20]. See Figure 7 for cooperation system based on voluntary disaster prevention organizations.

One of the important features of the research project was that the local disaster drills were held on the same day as the Sunday school visit day of the elementary and junior high schools, with the cooperation of local residents, children, students and their parents. The disaster drills held in 2015 were attended by about 1,000 local residents, who were informed about the contents of the district disaster prevention plan and the rules for evacuation shelters. See Figure 8 for disaster drills that included the participation of people with various professions from various generation. In addition, the junior high school students have taken the initiative to participate in the management of the evacuation shelters, encouraging them to change their mindset from being the ones to be helped to being the ones to help.

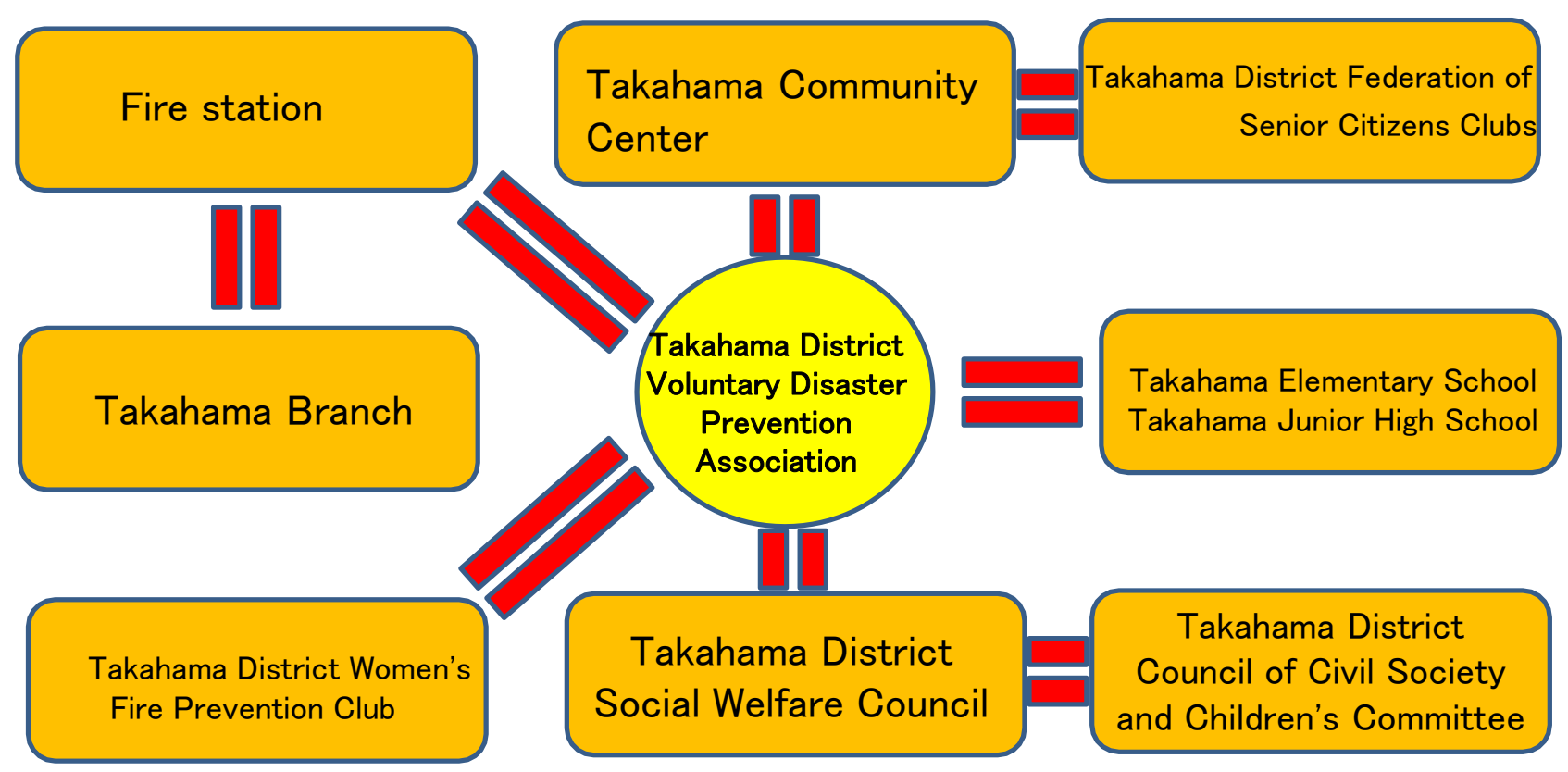

Figure 7 Cooperation system based on voluntary disaster prevention organizations [21] 


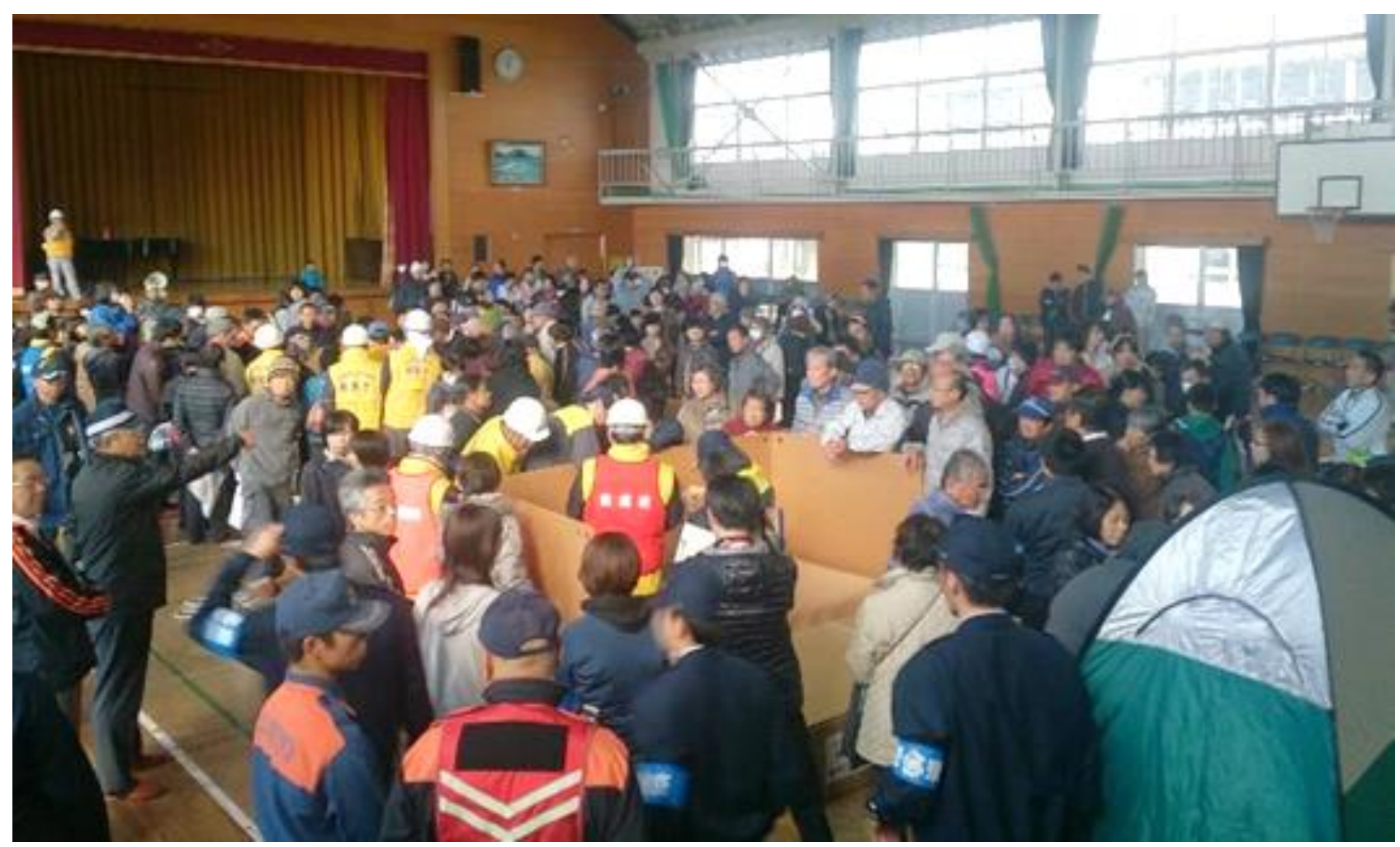

Figure 8 Disaster drills that included the participation of people with various professions from various generation [21]

\section{July 2018 Torrential Rains Disaster and the Effect of Areal Regulation}

In the Takahama district, drills were initially conducted with the purpose of evacuation from the coastal areas to higher grounds. Such a scheme was developed based on the past experience of hightide disasters and the expected damage caused by the Nankai Trough earthquake, which is expected to cause enormous damage. In other words, maritime threats were the most feared hazard in the district.

However, in 2015, Ehime Prefecture set up a sediment disaster warning area in the district. This fact had a great impact on the area. In other words, they were not expecting a sediment disaster to occur in their area. Before the establishment of the zone, the evacuation strategy of the community was to evacuate from the coastal area to higher ground. However, due to the establishment of the mentioned zone, it was realized that the designated evacuation zones at the higher grounds of the area was prone to sediment disasters.

This areal regulation led to new activities in the region. First, a response plan was developed for each type of disaster. Second, the participatory disaster prevention map, which was prepared for marinerelated hazards, was revised and a new evacuation site was set up for sediment disasters. The new evacuation sites were marked on the map and communicated to the residents in the district.

This new approach helped to successfully avoid any casualty in Takahama District during the sediment disaster caused by a prolonged heavy rainfall in July 2018. Known as the West Japan Torrential Rains, the disaster caused a large number of casualties, especially in Okayama, Hiroshima and Ehime Prefectures, while the number of evacuees reached 40,000 at its peak [22].

In the morning of 6 July 2018, the day before the damage occurred, a sediment disaster warning was issued for the whole of Matsuyama City. This information triggered the voluntary disaster prevention 
organizations to start patrolling the district in the afternoon. During the patrol, they noticed an anomaly and confirmed a mudslide, which became the main reason to perform door-to-door socialization on the evacuation from around $6 \mathrm{PM}$.

Furthermore, due to the sense of imminence of the disaster, the residents requested Matsuyama City to issue an evacuation order. At 9 PM, an evacuation order was issued for the area and a warning to evacuate was also issued by the local government. As a result, the information was delivered through a variety of channels, from the perspective of local residents who were familiar with the situation in their area, and from the government, which had the means to send out a simultaneous announcement.

After that, the rain reached its peak from around 10 PM to midnight and mudslides, as well as debris flows, occurred in 35 places in the district before dawn on the 7 July 2018. See Figure 9 for debris flowed into a residential area in Takahama District. Although it was the first time for the district to experience a sediment disaster, the evacuation was carried out without waiting for instructions from the government and everyone was safe.

This cooperation was possible because of the mutual understanding of the strengths of the voluntary disaster prevention organizations, which know the local community well, and the strengths possessed by the government. The government is able to deliver information such as evacuation advisories to many residents at the same time through Area E-mails and disaster prevention administrative radios. This is a great advantage that the residents do not have.

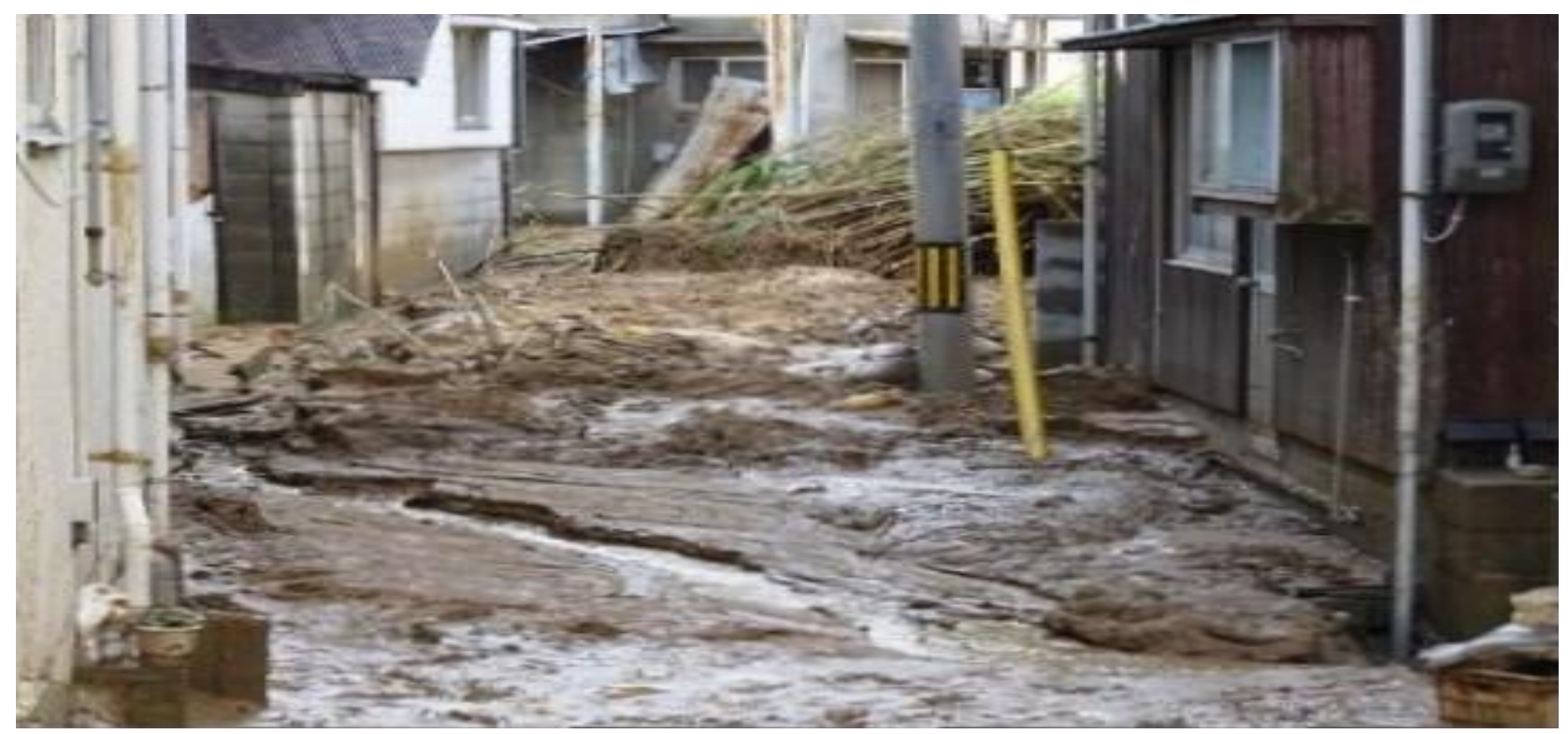

Figure 9 Debris flowed into a residential area in Takahama District

The voluntary disaster prevention organizations played a central role in the subsequent recovery and reconstruction of the district. The information was disseminated to the residents in the district by using circular boards. For example, information on how to dispose of debris and rubble according to the phase of life reconstruction, and information on support from the government for disaster victims.

Even during the typhoons that struck frequently during the subsequent recovery process, calm decisions were made based on the response measures for each disaster type, and evacuation notices were issued according to the characteristics of the hazard. 


\section{Discussion}

In this section, the development of CDR in Lembang Fault area is discussed. The themes of the discussion are the low level of participation on DRM, as well as the importance of government intervention on developing CDR that leads to the need of a sound land management strategy and land administration system. Furthermore, the discussion on the CDR development strategy based on demographic data and the importance of an organized community, as well as the strategy to allow the community to bounce back from the disaster is also given in this section. Additionally, an issue on the completeness of data for supporting the development of CDR is also discussed in this section.

The low level of participation on DRM may be caused by the lack of knowledge on DRM. Although the degree of understanding on the existing risks in Lembang Fault area was considerably high and there exists indigenous knowledge on DRM in the mentioned area, the knowledge to respond the disaster was very minimal. Also, there were only few people who know about the indigenous knowledge. Therefore, it is argued that a trigger is required to increase the level of people's participation.

It is also argued that government intervention will be crucial on development of CDR in Lembang Fault area, as such an intervention will act as one of the triggers on increasing people's participation. While the degrees of bonding and bridging with regard to social capital, risk knowledge including indigenous knowledge and past disaster experience were high, the levels of participation and people's capacity on DRM were however very low. The argument on the need of government intervention is supported by the fact that the degree of linking in the scope of social capital was considerably low. The respondents who were well-informed on the proneness of Lembang Fault area also stated that it is needed to perform simulations to response the possible disaster occurrence, disaster mitigation education and house structural reinforcement. DRM procedures were not available, as well as the organized governmental services. These facts contradicted to 2013 Municipal Decree on DRM that expects the local government to perform the above mentioned activities.

Furthermore, although the spatial plan urges the designation of the disaster-prone areas, as well as the development of evacuation routes and areas, the survey reveals that DRM infrastructure should still be established, while access to the existing DRM infrastructure is expected to be improved. Although the spatial plan regulates development in the disaster-prone areas, the extent of agricultural and settlement areas was continuously rising.

Based on the Japanese experience on the mentioned issue, it is also clear that government intervention is needed to develop CDR in Lembang Fault area. The Japanese government has enacted not only the basic regulations on DRM but also regulations that are specifically dealing with various types of disaster. Also, the activeness of the local government acted as the major point on development of CDR.

Having learned from the past disaster experiences in Indonesia and Japan, although it is a process run by government, land administration will also take an important role on development of CDR in Lembang Fault area. As mentioned at the Theory Section, spatial planning and land readjustment were among the critical activities at disaster recovery phase. A sound land tenure system had also contributed to the successful disaster recovery phase in the past. Spatial planning and land readjustment also acted as the means to develop CDR, as the main objective of the mentioned activities during disaster recovery phase was to create a disaster-resistant settlement area. Moreover, in Japan, the Sediment Disaster Prevention Act urges the establishment of sediment disaster-prone areas, which acts as one of land management strategies that is implemented by land administration. From the above examples, a sound land management strategy that is equipped with a good land 
administration system is expected to be established to develop CDR in Lembang Fault area. In fact, land management and administration act as the core of DRM and development of CDR.

Furthermore, from the case study of Lembang Fault area, land management strategy and land administration are expected to be developed based on the social, economic and environmental characteristics of the case study area. Based on the Japanese experience on the implementation the Sediment Disaster Prevention Act, land administration was performed by considering the social capital of people of Takahama District, particularly on bridging and linking, that was catalyzed by the voluntary disaster prevention organizations. Moreover, the environmental characteristics of Takahama District played an important role on the definition of evacuation areas from high tides. After the enactment of the Sediment Disaster Prevention Act, new evacuation zones were established by considering types of hazards in the mentioned district.

Considering the role of the voluntary disaster prevention organizations, it is also important to highlight the need to organize community to strengthen the linking aspect of social capital. From the survey, the vast coverage of Lembang Fault area could not be covered by the NGOs that have been performing their activities in the mentioned area. In the case that the level of people's participation and capacity on DRM in the case study area can be improved, they can be encouraged to establish voluntary disaster prevention organizations in every neighborhood. Thus, DRM in each neighborhood in Lembang Fault area may be performed by the local community. Also, the organized community may also link itself to the government. Particularly in Province of Western Java, such a proposal is in accordance with the provincial government program on development of Disaster-Resistant Village.

The strategy to allow the community to bounce back from the disaster is expected to be developed. From Japanese experience, the government has provided support for the redevelopment of livelihood after disaster. However, it may be difficult to rely on such a support. Furthermore, the development of CDR is expected to allow the community to bounce back with minimum external support. In Cisarua, Parongpong and Lembang District, people were mostly employed in agriculture sector. The disaster may interrupt agricultural activities, which, in turn, may disrupt groceries supply to the disaster-affected areas and even beyond those areas. It is therefore important to develop a strategy to allow the people to quickly return to their fields. On the other hand, a different strategy should be developed in Sukasari District. This is mainly because most people in the mentioned districts were employed in services area, which may be malfunctioning at a certain period after the disaster occurrence. Promoting economic resilience to disaster is substantially important, not only for people of Sukasari District but also for those in Cisarua, Parongpong and Lembang District.

Specific CDR development and DRM strategy may be developed based on gender and level of education in Lembang Fault area. As the proportion of women and men in Lembang Fault area is equal, CDR development and DRM strategy should consider gender sensitive issues. This is mainly to protect the safety of women and men during disaster response phase and transition from disaster response phase to disaster recovery phase. Also, by considering the level of education in each district, DRM education may be effective to be performed on elementary level as most people were elementary school graduates. For Lembang and Sukasari District, further DRM education may be given at high school level as more than $30 \%$ of the citizens of the districts were high school graduates. However, the amount of high school graduates in Cisarua and Parongpong District was considerably low, which will decrease the coverage of DRM education in the case that the education in the latter districts is given on high school level. The demographic data may also influence the level of DRM education that will be given to ensure the successfulness of the program.

To develop further DRM based on CDR in Lembang Fault area, it is expected that the baseline data should be completed, particularly on demography. As described in the findings section, data on population's age, disability and wealth was not available. From the Japanese experience, ageing 
population has become an obstacle on DRM. Thus, data collection on population's age is expected to be done. Moreover, the amount of diffable people is expected to be identified, as such data will provide an important input on development of DRM and CDR from the perspective of diffable people. Also, data on wealth is considerably important particularly to assess the capacity of the community to bounce back from the disaster.

\section{Conclusion}

The development of CDR in Lembang Fault area is principally possible. The concept on CDR provides a valuable guidance for such a development. However, it is important to perform a cross domain analysis to ensure the definition of appropriate strategies. Inclusion of land administration domain, on one hand, provides an example on cross domain analysis, while, on the other hand, it may not only act as one of the core components of DRM but also lead to development of CDR.

Moreover, government intervention is essential on development of CDR, particularly at disaster mitigation and response phase. Such an intervention may be beneficial to increase the level of people's participation and DRM capacity, which may lead to the development of an organized community to address DRM issues in the smallest geospatial unit as possible. The existence of organized community on DRM may lead to betterment of the circumstances concerning every subcategory of CDR assessment.

On the other hand, economic resilience to disaster is necessary to be developed to allow the people to quickly bounce back from disaster. While the research reveals the possibility on development of economic resilience to disaster in natural resources-rich areas, the conceptualizing of such a development is still expected to be done in areas with less or even no natural resources.

Most importantly, a detail data concerning domains and sub-categories of CDR assessment is expected to be initiated. A complete dataset will facilitate a more in-depth CDR assessment.

The outputs of the research that is highlighted in this paper are the result of assessment of community disaster resilience in a geological hazard-prone area, which is characterized by social, economic and environmental system of people and area of the central part of Western Java Province, Indonesia. The conceptual framework of the research may be implemented elsewhere by considering social, economic and environmental characteristics of the area in question. It may require adjustments for the application of the conceptual framework beyond the case study area of the research.

\section{References:}

1. UNISDR. 2009 UNISDR Terminology on Disaster Risk Reduction. Available online: https://www.preventionweb.net/files/7817_UNISDRTerminologyEnglish.pdf (accessed on 1 September 2021).

2. Keim, M.E. Building Human Resilience: The Role of Public Health Preparedness and Response as an Adaptation To Climate Change. Am J Prev Med 2008, 35(5), 508-516, doi: 10.1016/j.amepre.2008.08.022.

3. Pfefferbaum, R.L.; Pfefferbaum, B.; van Horn, R.L.; Klomp, R.W.; Norris, F.H.; Reissman, D.B. The Communities Advancing Resilience Toolkit (CART): An Intervention to Build Community Resilience to Disasters. J. of Public Health Management and Practice 2013,19(3), 250258, doi: 10.1097/PHH.0b013e318268aed8.

4. Cutter, S.L.; Ahearn, J.A,; Amadei, B.; Crawford, P.; Eide, E.A.; Galloway, G.E.; Goodchild, M.F.; Kunreuther, H.C.; Li-Volmer, M.; Schoch-Spana, M.; Scrimshaw, S.C.; Stanley, E.M.; Whitney, G.; Zoback, M.L. Disaster Resilience: A National Imperative. Environment 2013, 55(2), 25-29, doi: 10.1080/00139157.2013.768076 
5. Viverita, V.; Kusumastuti, R.D.; Husodo, Z.A.; Suardi, L.; Danarsari, D.N. Households Perceptions on Factors Affecting Resilience towards Natural Disasters in Indonesia, The South East Asian J. of Manag. 2014, 8(1), 13-28, doi: 10.21002/seam.v8i1.3099.

6. Wijagsono, O.; Muryani, C.; Prihadi, S. Community Resilience and Adaptation Strategy of Flood Disaster in Trucuk District Bojonegoro Regency. GeoEco J. 2019, 5(2), 181-191, doi: $10.20961 /$ ge.v5i2.35648

7. Shalih, O.; Setiadi, H.; Nurlambang, T.; Sumadio, W. Toward a Community Resilience Framework for Disaster Risk Management: A Case Study Landslide Cisolok in Sukabumi 2018 and Sunda Strait Tsunami in Pandeglang 2018. In E3S Web of Conferences 2020, 156(01011), Proceeding of $4^{\text {th }}$ ICEEDM, Padang, Indonesia, 26-27 September 2019; University of Andalas: Padang, Indonesia, 2019; doi: 10.1051/e3sconf/202015601011

8. Abdulharis, R. Land Administration in Post-Disaster Areas: Case Study of Banda Aceh, Indonesia. M.Sc. Thesis, Delft University of Technology, Delft, The Netherlands, 2 October 2006

9. Meilano, I.; Abidin, H.Z.; Andreas, H.; Gumilar, I.; Sarsito, D.; Hanifa, R.; Rino; Harjono, H.; Kato, T.; Kimata, F; Fukuda, Y. Slip Rate Estimation of the Lembang Fault West Java from Geodetic Observation. J. Disaster Res. 2012, 7(1), 12-18, doi: 10.20965/jdr.2012.p0012

10. Daryono, M.R.; Natawidjaja, D.H.; Sapiie,B.; Cummins, P. Tectonophysics Earthquake Geology of the Lembang Fault, West Java, Indonesia. Tectonophysics 2019, 751, 180-191, doi: 10.1016/j.tecto.2018.12.014

11. Teo, M.; Goonetilleke, A.; Ziyath, A. An Integrated Framework for Assessing Community Resilience in Disaster Management. In Proceedings of the 9th Annual International Conference of the International Institute for Infrastructure Renewal and Reconstruction, Brisbane, Australia, 8-10 July 2013; Barnes, Goonetilleke, Eds.; Queensland University of Technology: Brisbane, Australia, 2015; 309-314

12. Ostadtaghizadeh, A.; Ardalan, A.; Paton, D.; Jabbari, H.; Khankeh, H.R. Community Disaster Resilience: A Systematic Review on Assessment Models and Tools. PLOS Currents Disasters 2015, April 8(1), doi: 10.1371/currents.dis.f224ef8efbdfcf1d508dd0de4d8210ed.

13. Williamson, I.; Enemark, S.; Wallace, J.; Rajabifard, A. Land Administration for Sustainable Development; ESRI: Redlands, 2010; ISBN 978-1-58948-041-4

14. Dale, P.; McLaughlin, J. Land Administration; Oxford University Press: New York, 1999; ISBN 978-0-19823-390-9

15. Unger, E.; Bennet, R.; Lemmen, C.; Dijkstra, P. Bridging the Gap of Land Administration and Disaster Risk Management: A Key Step in Climate Change Response. In Proceeding of FIG Working Week 2020 Smart Surveyors for Land and Water Management, Amsterdam, the Netherlands, 10-14 May 2020; Abstract number 10702.

16. Widiantono, D.J.; Supriatna, A.; Nugroho, W.A.; Abdulharis, R. Konsolidasi Tanah dalam rangka Penataan Kawasan Pasca Bencana Gempa Bumi di Kabupaten Lombok Utara, Provinsi Nusa Tenggara Barat. Buletin Penataan Ruang 2019, 1, 23-30.

17. Handayani, A. Sukses Konsolidasi Tanah Pasca Bencana. Media Indonesia, 8 Juni 2021, 10.

18. Ministry of Land, Infrastructure, Transport and Tourism. Outline of the Sediment Hazard Prevention Act. Japan. nd

19. Ministry of Land, Infrastructure, Transport and Tourism. Status of Designation of Sediment Disaster Prevention Areas as of the End of March 2021. Available online: https://www.mlit.go.jp/common/001406980.pdf (Accessed 1 September 2021).

20. Isouchi, C.; Tsuda, Y.; Nonomura, A. Proposal on Developmental Use of District Disaster Prevention Plan System in Flood Disaster High Risk Area: Case Study of Measures for People Who Need Support For Evacuation Action in July 2018 Torrential Rain Disaster. J. of Civ. Eng. F6 (Safety Issues) 2019, 75(2), I_75-I_82; doi: https://doi.org/10.2208/jscejsp.75.2_I_75.

21. Kagehara (Takahama District, City of Matsuyama, Ehime Prefecture, Japan). Personal communication, nd.

22. Fire and Disaster Management Agency. White Paper on Fire and Disaster Management. Ministry of Internal Affairs and Communications, Japan. 2018. 
